\title{
Calcitriol restores antiestrogen responsiveness in estrogen receptor negative breast cancer cells: A potential new therapeutic approach
}

\author{
Nancy Santos-Martínez ${ }^{1,2 \dagger}$, Lorenza Díaz ${ }^{1 \dagger}$, David Ordaz-Rosado', Janice García-Quiroz,2, David Barrera', \\ Euclides Avila', Ali Halhali ${ }^{1}$, Heriberto Medina-Franco ${ }^{3}$, María J Ibarra-Sánchez ${ }^{4}$, José Esparza-López \\ Javier Camacho ${ }^{2}$, Fernando Larrea ${ }^{1}$ and Rocío García-Becerra ${ }^{1 *}$
}

\begin{abstract}
Background: Approximately 30\% of breast tumors do not express the estrogen receptor (ER) a, which is necessary for endocrine therapy approaches. Studies are ongoing in order to restore ERa expression in ERa-negative breast cancer. The aim of the present study was to determine if calcitriol induces ERa expression in ER-negative breast cancer cells, thus restoring antiestrogen responses.

Methods: Cultured cells derived from ERa-negative breast tumors and an ERa-negative breast cancer cell line (SUM-229PE) were treated with calcitriol and ERa expression was assessed by real time PCR and western blots. The ERa functionality was evaluated by prolactin gene expression analysis. In addition, the effects of antiestrogens were assessed by growth assay using the XTT method. Gene expression of cyclin D1 (CCND1), and Ether-à-go-go 1 (EAG1) was also evaluated in cells treated with calcitriol alone or in combination with estradiol or ICl-182,780. Statistical analyses were determined by one-way ANOVA.
\end{abstract}

Results: Calcitriol was able to induce the expression of a functional ERa in ER-negative breast cancer cells. This effect was mediated through the vitamin D receptor (VDR), since it was abrogated by a VDR antagonist. Interestingly, the calcitriol-induced ERa restored the response to antiestrogens by inhibiting cell proliferation. In addition, calcitriol-treated cells in the presence of ICI-182,780 resulted in a significant reduction of two important cell proliferation regulators CCND1 and EAG1.

Conclusions: Calcitriol induced the expression of ERa and restored the response to antiestrogens in ERa-negative breast cancer cells. The combined treatment with calcitriol and antiestrogens could represent a new therapeutic strategy in ERa-negative breast cancer patients.

Keywords: Estrogen receptor, Breast cancer, Hormonal therapy, Calcitriol, VDR

\section{Background}

Breast cancer is a heterogeneous disease, encompassing a number of distinct biological entities that are associated with a variety of pathological and clinical features [1]. The gene expression profile of breast cancer allows to classify this disease in five groups, two of them estrogen receptor (ER)-positive (luminal

\footnotetext{
*Correspondence: rocio.garciab@quetzal.innsz.mx

${ }^{\dagger}$ Equal contributors

'Departments of Reproductive Biology, Instituto Nacional de Ciencias Médicas y Nutrición Salvador Zubirán, Vasco de Quiroga No. 15, Tlalpan 14000 México, México

Full list of author information is available at the end of the article
}

$\mathrm{A}$ and B) and three ER-negative (normal breast-like, human epidermal growth factor receptor- 2 (HER2) and basal-like) [2]. Approximately $30 \%$ of all breast tumors do not express ER, a protein with both prognostic and predictive values. Indeed, the presence of $E R \alpha$ correlates with increased disease-free survival and better prognosis. Importantly, ER $\alpha$-positive breast cancers respond appropriately to endocrine therapies [3-5]. Tamoxifen is the most common and effective therapy in pre- and postmenopausal patients affected with ER-positive tumors, since a long-term use of this compound increases disease-free survival and reduces

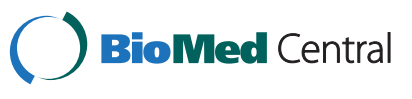


tumor recurrence [6,7]. Unfortunately, up to $50 \%$ of patients bearing ER $\alpha$-positive primary tumors lose receptor expression in recurrent tumors, and about one third of metastatic tumors develop resistance to tamoxifen and lose ER $\alpha$ expression [8]. The lack of ER expression has been linked to epigenetic mechanisms or to others such as hyperactivation of the mitogen-activated protein kinase (MAPK) signaling pathway or increased expression of specific microRNAs [9-11]. In fact, knockdown of specific microRNAs or inhibition of MAPK activity is followed by restoration of a functional ER $\alpha$ in ER-negative breast cancer cells $[9,10]$. These findings indicate that the ER $\alpha$-negative phenotype could be reverted for therapeutic purposes.

Calcitriol, the most active metabolite of vitamin $D$, elicits significant antiproliferative activity in breast cancer cells by several vitamin D receptor (VDR) mediated mechanisms including regulation of growth arrest, cell differentiation, migration, invasion and apoptosis [12-14]. Epidemiological studies have demonstrated an association between low levels of calcidiol, the precursor of calcitriol, and increased risk of developing breast cancer [15]. Moreover, low levels of calcitriol are associated with disease progression and high incidence of ER-negative and triple-negative breast tumors [16,17], while VDRpositive breast cancer patients had significantly longer disease-free survival than those with VDR-negative tumors [18]. Indeed, VDR knock-out mice are more likely to develop ER- and progesterone receptor (PR)negative mammary tumors as compared with their wild type littermates [17], highlighting calcitriol prodifferentiating properties. Our laboratory and other groups have demonstrated the potent antipropiferative activity of calcitriol in cells derived from biopsies or in established cell lines from breast cancer [19-21]. Additionally, other studies have demonstrated the antiproliferative effects of vitamin D compounds in ER-responsive human breast cancer cells through downregulation of ER and disruption of estrogen dependent signaling pathways $[20,22,23]$. However, calcitriol also inhibited proliferation in ER-negative cell lines, suggesting that growth inhibition induced by calcitriol is not solely mediated through the ER [12]. In this regard, ER $\alpha$ regulation studies in several human breast cancer cell lines showed that calcitriol treatment decreased or did not modify ER expression [20,22-24]. In contrast, in an ER-negative breast cancer cell line calcitriol increased estrogen binding proteins [24].

In order to increase our knowledge concerning the participation of calcitriol in ER regulation, the aim of the present study was to investigate if this hormone induces a functional ER and consequently could restore the antiproliferative effects of antiestrogens in ER-negative breast cancer cells.

\section{Methods}

\section{Reagents}

Estradiol $\left(\mathrm{E}_{2}\right)$, 4-hydroxytamoxifen and calcipotriol (MC 903) were purchased from Sigma (St. Louis, MO, USA). Cell culture medium was obtained from Life Technologies (Grand Island, NY, USA). Fetal bovine serum (FBS) was from Hyclone Laboratories Inc. (Logan, UT, USA) and the antiestrogen ICI-182,780 (Fulvestrant) from Zeneca Pharmaceuticals (Wilmington, DE, USA). Gefitinib (Iressa, ZD1839) was kindly provided by AstraZeneca (Wilmington, DE, USA). U0126 was from Millipore (MA, USA). Trizol and the oligonucleotides for real time polymerase chain reaction (qPCR) were from Invitrogen (CA, USA). The TaqMan Master reaction, probes, capillaries, reverse transcription (RT) system and the cell proliferation assay (XTT) were purchased from Roche (Roche Applied Science, IN, USA). MCF-7 nuclear extract was purchased from Santa Cruz Biotechnology Inc., (CA, USA). The VDR antagonist (23S)-25-dehydro-1-hydroxyvitamin D3-26,23lactone (TEI-9647) and 1 $\alpha, 25$-dihydroxycholecalciferol (calcitriol) were kindly donated from Teijin Pharma Limited (Tokyo, Japan) and Hoffmann-La Roche Ltd. (Basel, Switzerland), respectively.

\section{Human tissues}

The protocol was approved by the Institutional Review Board "Comité Institucional de Investigación Biomédica en Humanos (No. 1967, 2009)" of the "Instituto Nacional de Ciencias Médicas y Nutrición Salvador Zubirán (Mexico City). Before mammary biopsies donation, all participating patients signed an informed consent. Biopsies were obtained from patients with ER-negative breast cancer. The samples were harvested and processed as described previously [19]. A total of 5 independent cultured specimens were used for this study. The ER-negative SUM-229PE (Asterand, San Francisco, CA) and the ER-positive BT-474 (ATCC) and MCF-7 (ATCC) established cell lines were also studied.

\section{Cell culture}

Primary tumor cultures were derived from biopsies of breast cancer patients as described previously $[19,25]$. The cells were cultured in DMEM-HG medium supplemented with $5 \%$ heat-inactivated-FBS, $100 \mathrm{U} / \mathrm{ml}$ penicillin, $100 \mu \mathrm{g} / \mathrm{ml}$ streptomycin; and incubated in $5 \%$ $\mathrm{CO}_{2}$ at $37^{\circ} \mathrm{C}$. After approximately 8 passages cells were characterized by western blot and immunocytochemistry. Established cell lines were maintained according to indications from suppliers. All experimental procedures were performed in DMEM-F12 medium supplemented with 5\% charcoal-stripped-heat-inactivated FBS, $100 \mathrm{U} / \mathrm{ml}$ penicillin and $100 \mu \mathrm{g} / \mathrm{ml}$ streptomycin. 


\section{Immunocytochemistry}

Cultured cells were grown on glass coverslips and fixed in $96 \%$ ethanol. Antigen retrieval was done by autoclaving in EDTA decloaker $5 \times$ solution ( $\mathrm{pH}$ 8.4-8.7, Biocare Medical, CA, USA) during $10 \mathrm{~min}$. Slides were blocked with immunodetector peroxidase blocker (Bio SB, CA, USA) and incubated with ER $\alpha$ (1:250, Bio SB) [26] and VDR antibodies (1:100, Santa Cruz Biotechnology Inc, CA, USA) [27]. After washing, the slides were sequentially incubated with immune-Detector Biotin-Link and Immuno-Detector HRP label (Bio SB) during 10 min each. Staining was completed with $\mathrm{DAB}$ and $0.04 \% \mathrm{H}_{2} \mathrm{O}_{2}$.

\section{Western blots}

Cells were incubated in the presence of calcitriol $\left(1 \times 10^{-8} \mathrm{M}\right.$

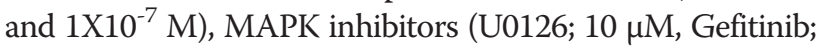
$0.8 \mu \mathrm{M})$ or the vehicle alone during $72 \mathrm{hr}$. Afterwards, whole-cell protein lysates were prepared using lysis buffer $(50 \mathrm{mM}$ Tris- $\mathrm{HCl}, 150 \mathrm{mM} \mathrm{NaCl}, 1 \%$ Nonidet $\mathrm{P}-40, \mathrm{pH} 7.5)$ in the presence of a protease inhibitor cocktail. Protein concentrations were determined using the Protein Assay Dye Reagent Concentrate (Bio-Rad, Hercules, CA, USA). The proteins were separated on 10\% SDS-PAGE and transferred to nitrocellulose membranes. The membranes were blocked with $5 \%$ skim milk and incubated overnight at $4{ }^{\circ} \mathrm{C}$ in the presence of mouse anti-ER $\alpha$ (1:200, Santa Cruz) [28]. The membranes were washed and incubated with goat anti-mouse HRPconjugated secondary antibody (1:2000, Santa Cruz). For visualization, membranes were processed with $\mathrm{BM}$ chemiluminescence blotting substrate (Roche Applied Science, IN, USA). For normalization, blots were stripped in boiling stripping buffer $(2 \% \mathrm{w} / \mathrm{v}$ SDS, $62.5 \mathrm{mM}$ Tris- $\mathrm{HCl}$ $\mathrm{pH} 6.8,100 \mathrm{mM} 2$ - mercapto-ethanol) for $30 \mathrm{~min}$ at $50^{\circ} \mathrm{C}$ and sequentially incubated with mouse anti-GAPDH (1:10000, Millipore) [29] and anti-mouse-HRP (1:10000, Jackson ImmunoResearch Laboratories, Inc., West Grove, PA, USA). Densitometric analysis of resulting bands was performed by using Image software (NIH, USA).

\section{Cell proliferation assay}

The cells were seeded in 96-well tissue culture plates at a density of 500-1000 cells/well by sextuplicate. After incubating for $24 \mathrm{hr}$, cells were incubated in the presence or absence of calcitriol $\left(1 \times 10^{-8} \mathrm{M}\right)$ during $48 \mathrm{hr}$. Afterwards, culture medium was removed and incubations with $E_{2}$ $\left(1 \mathrm{X} 10^{-8} \mathrm{M}\right)$, as an ER agonist, or tamoxifen $\left(1 \mathrm{X}^{-6} \mathrm{M}\right)$ and

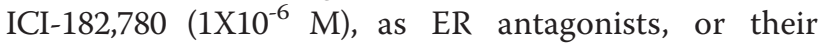
combination were performed in the absence or presence of calcitriol. Plates were incubated at $37^{\circ} \mathrm{C}$ for 6 days and cell viability was determined by using the colorimetric XTT Assay Kit (Roche) according to manufacturer's instructions. After $4 \mathrm{hr}$ incubation, absorbance at $492 \mathrm{~nm}$ was measured in a microplate reader (BioTek, Winooski, VT, USA).

\section{Real time RT-PCR}

For $E R \alpha$ gene expression analysis the cells were incubated in the presence of different calcitriol concentrations or the vehicle alone $(0.1 \%$ ethanol) during $24 \mathrm{hr}$. In order to establish the participation of the VDR on calcitriol effects upon the $E R \alpha$, the VDR antagonist TEI-9647 $\left(1 \times 10^{-6} \mathrm{M}\right)$ was coincubated with calcitriol in some experiments. Gene expression analyses of prolactin (PRL), cyclin D1 (CCND1) and the potassium channel Ether-à-go-go (EAG1) were also performed. For this, the cells were treated with calcitriol $\left(1 \mathrm{X} 10^{-8} \mathrm{M}\right)$ during $48 \mathrm{hr}$. Afterwards, $\mathrm{E}_{2}\left(1 \mathrm{X} 10^{-8} \mathrm{M}\right)$ or ICI-182,780 $\left(1 \times 10^{-6} \mathrm{M}\right)$ were added to the culture media and the incubations proceeded for additional $24 \mathrm{hr}$. Next, RNA was extracted with Trizol reagent and then subjected to reverse transcription using the transcriptor RT system. Real-time PCR was carried out using the LightCycler 2.0 from Roche (Roche Diagnostics, Mannheim, Germany), according to the following protocol: activation of Taq DNA polymerase and DNA denaturation at $95^{\circ} \mathrm{C}$ for $10 \mathrm{~min}$, proceeded by 45 amplification cycles consisting of $10 \mathrm{~s}$ at $95^{\circ} \mathrm{C}, 30 \mathrm{~s}$ at $60^{\circ} \mathrm{C}$, and $1 \mathrm{~s}$ at $72^{\circ} \mathrm{C}$. The following oligonucleotides were used: $E R \alpha-\mathrm{F}, \mathrm{CCTTCTTCAAGAGAAGTA}$ TTCAAGG; $E R \alpha-R$, GTTTTTATCAATGGTGCACTGG; EAG1-F, CCTGGAGGTGATCCAAGATG; EAG1-R, CCA AACACGTCTCCTTTTCC; CCND1-F, GAAGATCGTCG CCACCTG; CCND1-R, GACCTCCTCCTCGCACTTCT; PRL-F, AAAGGATCGCCATGGAAAG; PRL-R, GCACAG GAGCAGGTTTGAC. The gene expression of the housekeeping gene glyceraldehyde-3-phosphate dehydrogenase (GAPDH) GAPDH-F, AGCCACATCGCTGAGA CAC; GAPDH-R, GCCCAATACGACCAAATCC was used as an internal control. Stimulatory concentration $\left(\mathrm{EC}_{50}\right)$ values were obtained by non-linear regression analysis using sigmoidal fitting with a dose-response curve by means of a scientific graphing software (SigmaStat, Jandel Scientific).

\section{Statistical analyses}

Data are expressed as the mean \pm standard deviation (S.D.). Statistical analyses were determined by one-way ANOVA followed by the Holm-Sidak method, using a specialized software package (SigmaStat, Jandel Scientific). Differences were considered significant at $P \leq 0.05$.

\section{Results}

Calcitriol induced ERa expression through a VDRdependent mechanism in ER-negative breast cancer cells Biopsies from five patients with ER-negative breast cancer were obtained and used for cell culturing. These biopsies had a diagnosis of invasive ductal carcinoma and ranged between 5 and 9 in the Scarff-Bloom-Richardson 
system score. All cultured breast tumor-derived cells were positive for VDR and further confirmed to be negative for ER $\alpha$ (Figure 1). In addition, the ER-negative SUM-229PE and ER-positive BT-474 established cell lines were also studied. All cell lines were incubated in the presence of calcitriol $\left(1 \times 10^{-7} \mathrm{M}\right)$ during $24 \mathrm{hr}$ and $E R \alpha$ gene expression was assessed by qPCR. As shown in Figure 2A, calcitriol significantly induced $E R \alpha$ mRNA expression in all tumor-derived cultured cells and SUM-229PE cells. In contrast, calcitriol downregulated ER $\alpha$ mRNA levels in BT-474 as it has been previously reported [30].

As shown in Figure 2B, calcitriol significantly increased $E R \alpha$ mRNA in a dose dependent manner with an $\mathrm{EC}_{50}$ of $9.8 \times 10^{-9} \mathrm{M}$. This effect was specifically mediated through the VDR, since the VDR antagonist TEI-9647 significantly abolished the stimulatory effect of calcitriol upon ERa gene expression. The presence of the VDR antagonist by itself did not modify $E R \alpha$ gene expression (Figure $2 \mathrm{C}$ ).

In order to assess if calcitriol induced ER $\alpha$ protein expression, the SUM-229PE cell line was incubated in the presence of calcitriol and western blot analyses were performed. Figure 3 shows the results of cells incubated with two calcitriol concentrations $\left(1 \times 10^{-8}\right.$ and $\left.1 \times 10^{-7} \mathrm{M}\right)$ during $72 \mathrm{hr}$. The presence of a $66 \mathrm{KDa}$ band corresponding to ER $\alpha$, as judged by the positive control in MCF-7 cells, was observed in calcitriol-treated cells. Moreover, a higher calcitriol concentration further increased the relative abundance of ER $\alpha$ as shown in Figure 3. Inhibitors of the MAPK signaling pathway (U0126 and Gefitinib) were used as controls of ER $\alpha$ induction [10].

\section{Calcitriol induced a functional ERa}

In order to determine the functionality of the $E R \alpha$ induced by calcitriol, we evaluated the effects of $E_{2}$ and the antiestrogen ICI-182,780 on the expression of PRL, cathepsin D (CTSD) and trefoil factor 1 (TFF1) as examples of estrogen inducible genes [31]. Breast tumor-derived cells were cultured first in the presence or absence of calcitriol $\left(1 \times 10^{-8} \mathrm{M}\right)$ during $48 \mathrm{hr}$ and subsequently incubated in the presence of $\mathrm{E}_{2}\left(1 \times 10^{-8} \mathrm{M}\right)$ or ICI-182,780 $\left(1 \times 10^{-6} \mathrm{M}\right)$ with or without calcitriol for $24 \mathrm{hr}$ (Figure 4). In the absence of calcitriol (black bars), $\mathrm{E}_{2}$ and ICI-182,780 did not modify PRL mRNA; however, in calcitriol-treated cells (white bars), $\mathrm{E}_{2}$ significantly

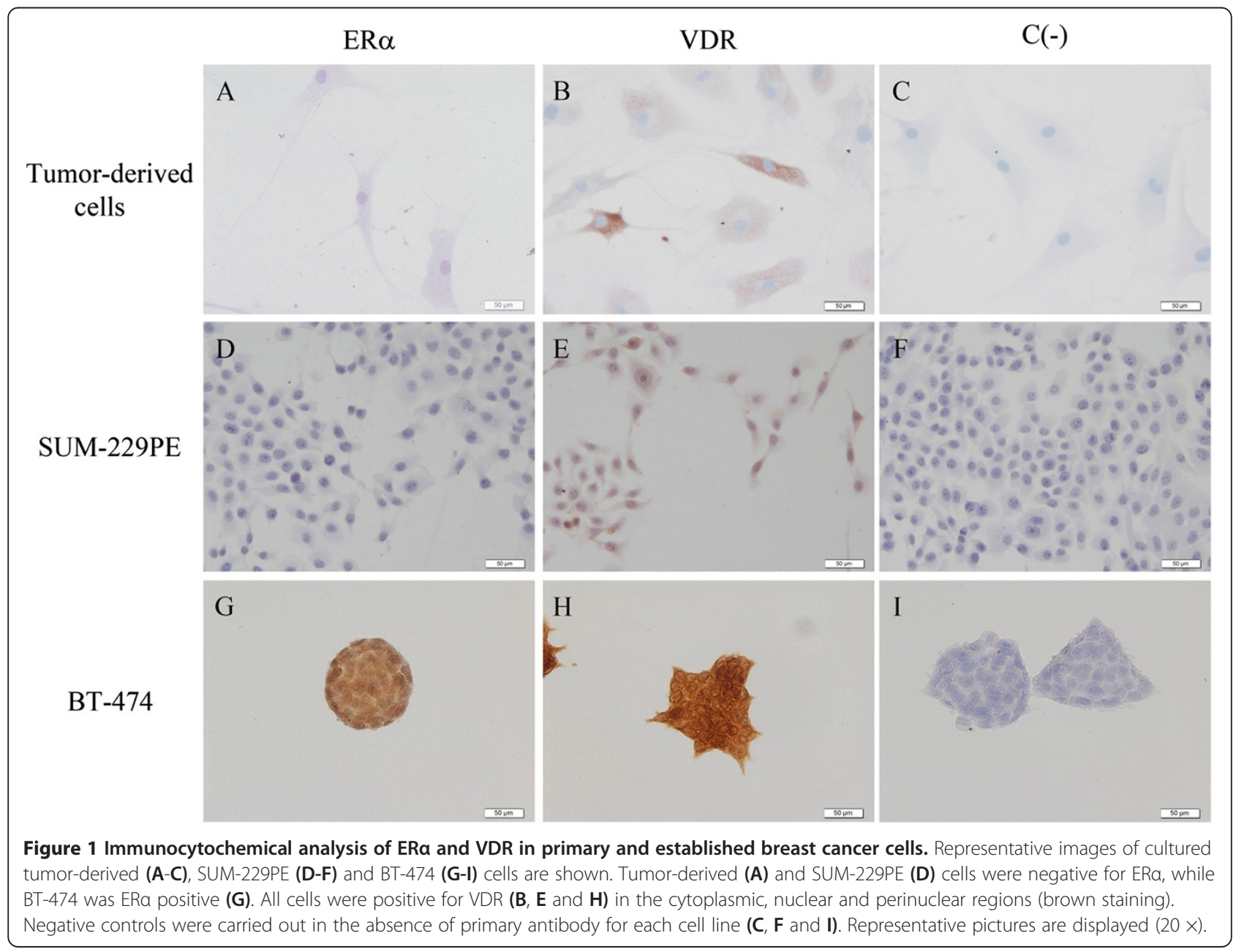




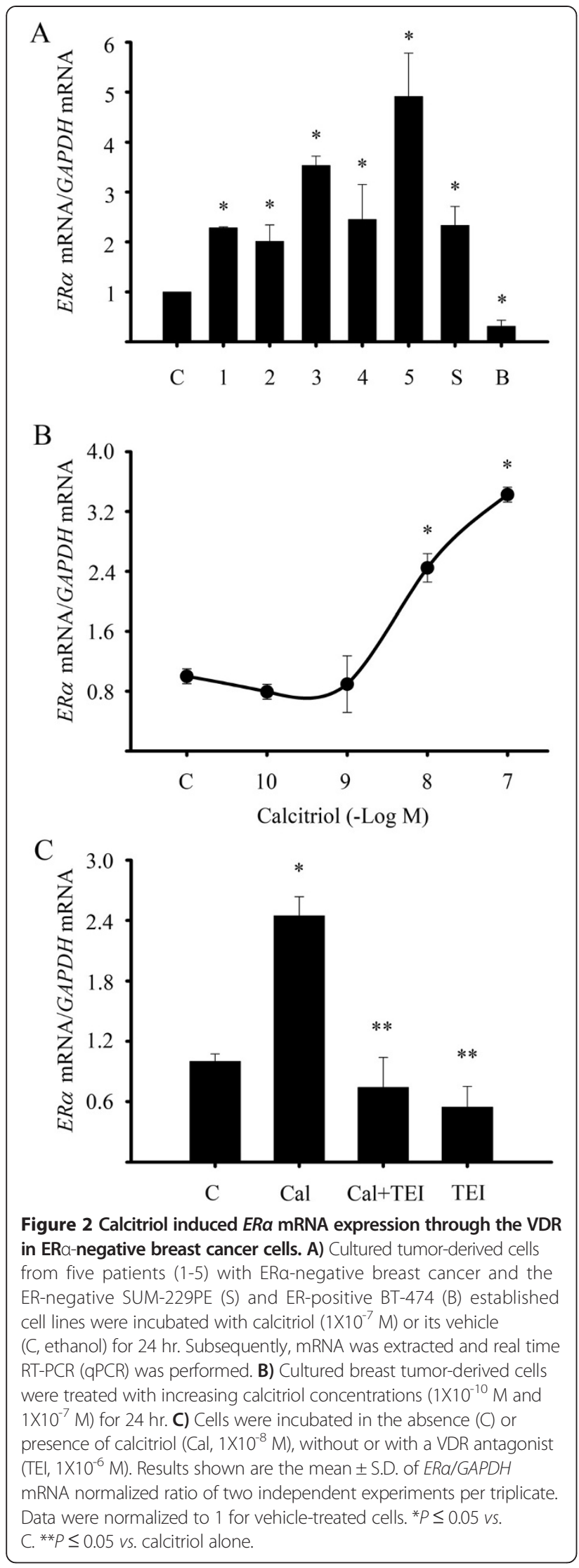

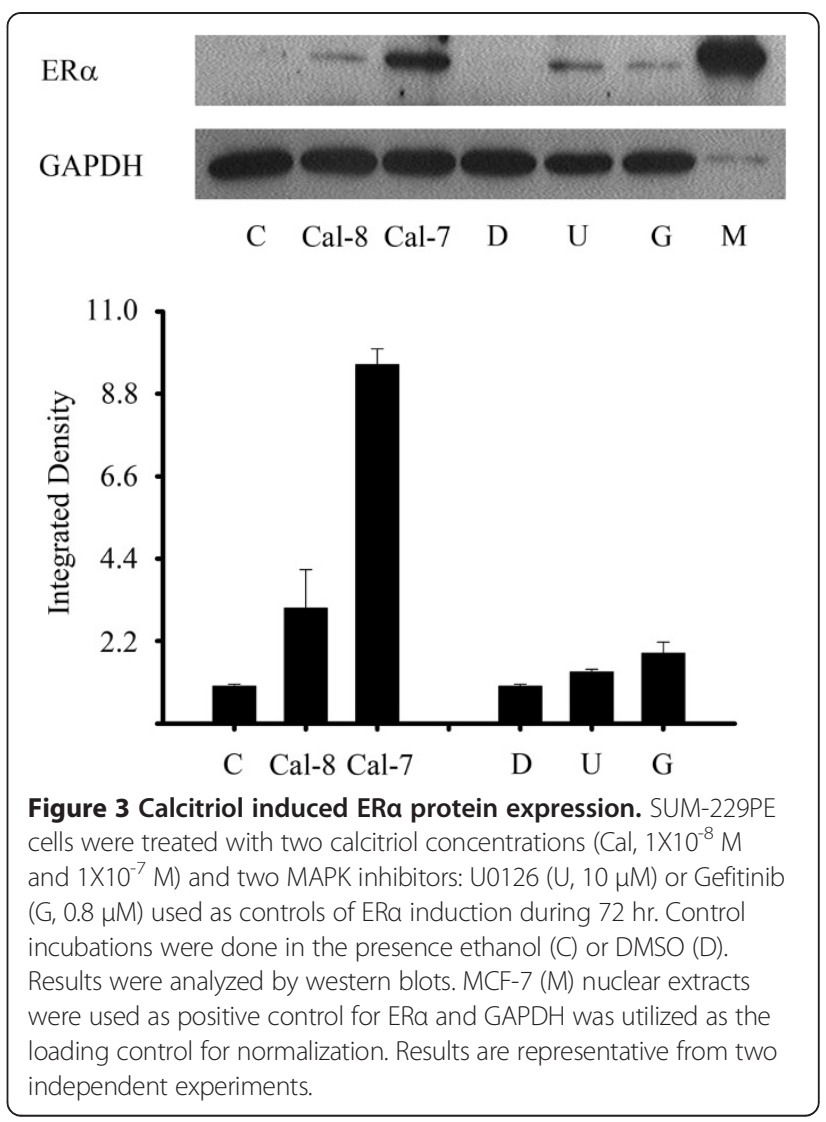

upregulated PRL expression. The presence of the antiestrogen alone did not change $P R L$ gene expression. These data suggest that the calcitriol-induced ER $\alpha$ is a fully-transcriptionally active receptor. Interestingly, calcitriol per se significantly stimulated the expression of both CTSD and TFF1 genes, which may explain why E2 was not able to further increase gene expression (data not shown).

\section{Calcitriol restored the antiestrogenic response in ERa-negative breast cancer cells}

In order to assess whether the calcitriol-induced ER $\alpha$ was sensitive to the antiproliferative effects of the antiestrogens in ER $\alpha$-negative breast cancer cells, growth assays were performed. Breast cancer cells were incubated in the presence of calcitriol $\left(1 \times 10^{-8} \mathrm{M}\right)$ or the vehicle alone for $48 \mathrm{hr}$. Afterwards, cells were incubated with ER agonist $\left(1 \times 10^{-8} \mathrm{M}\right)$, antagonists $\left(1 \times 10^{-6} \mathrm{M}\right)$ or the combination of $E_{2}$ plus antagonists during 6 days. The results demonstrated that in the absence of calcitriol (black bars), none of the compounds affected cell growth in both cultured breast tumor-derived cells (Figure 5A) and the SUM-229PE cell line (Figure 5B). Interestingly, in calcitriol-treated tumor-derived cells (white bars), antiestrogens alone or in combination with $\mathrm{E}_{2}$ significantly inhibited cell proliferation as compared with control cells 


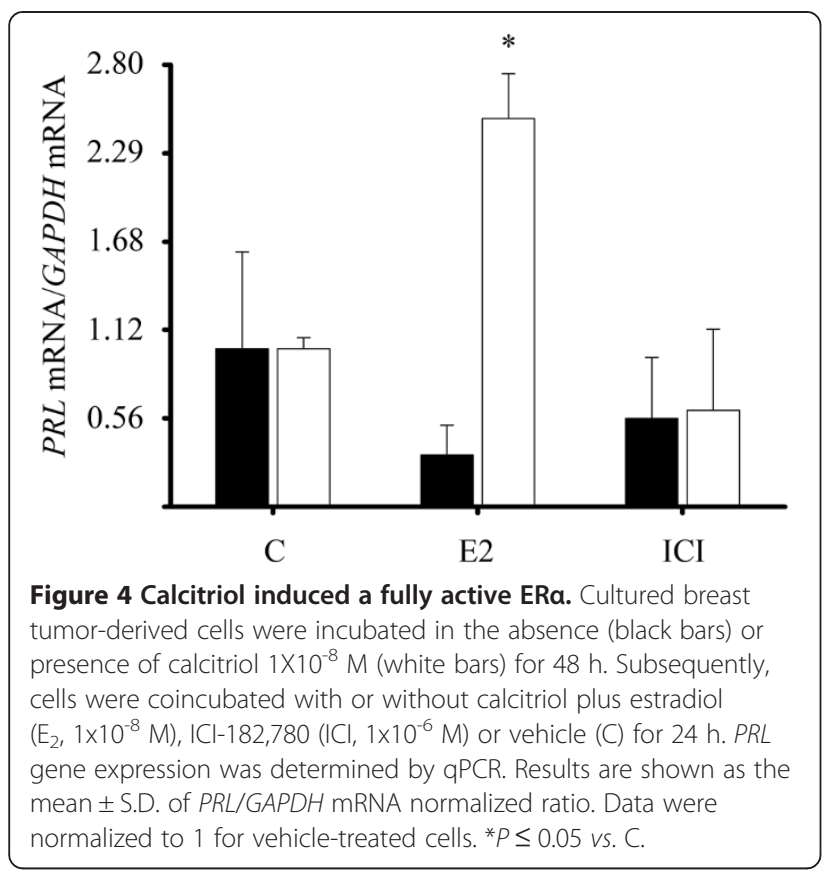

(C, white bar). The presence of $E_{2}$ at the dose of $1 \times 10^{-8} \mathrm{M}$ did not modify cell growth (Figure $5 \mathrm{~A}$ ); however, higher $\mathrm{E}_{2}$ concentrations $\left(1 \mathrm{X} 10^{-7} \mathrm{M}\right)$ significantly inhibited cell growth (data not shown). Similar results were observed in SUM-229PE cells, but tamoxifen alone or in combination with $\mathrm{E}_{2}$ did not affect cell growth (Figure 5B). MCF-7 cells were used as control of the inhibitory effect of the antiestrogens via ER $\alpha$ (Figure 5C). As depicted, $\mathrm{E}_{2}$ significantly increased cell proliferation in cells not treated with calcitriol; however, this effect was not observed in those cells cultured in the presence of calcitriol, most likely due to its antiproliferative activity. As expected, antiestrogens and their combination with $E_{2}$ significantly inhibited cell growth in both treated and not-treated calcitriol cells.

\section{Antiestrogen treatment downregulated CCND1 and EAG1} gene expression in calcitriol-treated breast cancer cells One of the molecular mechanisms by which antiestrogens inhibit cell proliferation is by decreasing CCND1 expression and blockage of cell cycle progression via the ER [32,33]. Thus, we studied the effects of ICI-182,780 and $\mathrm{E}_{2}$ on CCND1 expression in calcitriol-treated $E R \alpha$-negative breast tumor-derived cells. As shown in Figure 6A, only in calcitriol-treated cells the presence

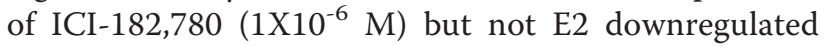
CCND1 gene expression.

In breast cancer cell lines the inhibition of EAG1 potassium channel expression is accompanied by a significant reduction of cell proliferation [19,34]. Therefore, we evaluated the effects of an agonist or antagonist of the calcitriol-induced ER on EAG1 expression. As shown in

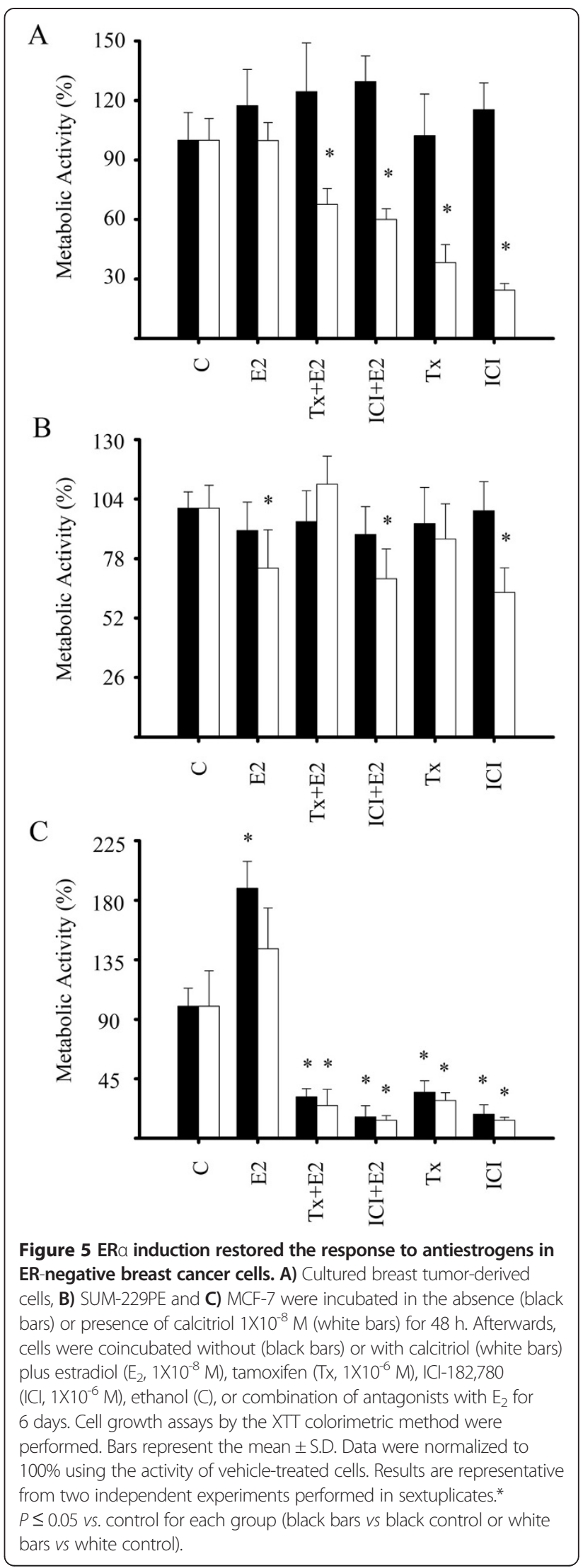




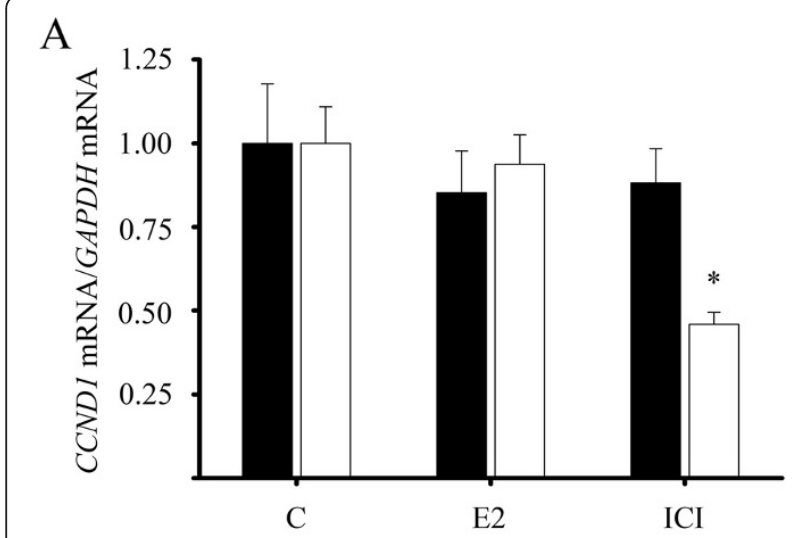

$\mathrm{B}$

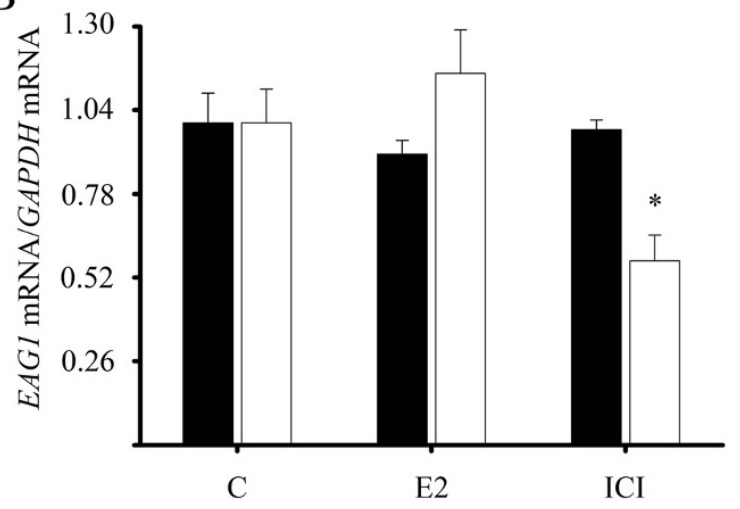

Figure 6 ICI-182,780 downregulated CCND1 and EAG1 gene expression in calcitriol-treated ERa-negative cells. Cultured breast tumor-derived cells were incubated in the absence (black bars) or presence of calcitriol $1 \times 10^{-8} \mathrm{M}$ (white bars) for $48 \mathrm{~h}$. Subsequently, cells were coincubated with or without calcitriol plus estradiol ( $E_{2}$ $\left.1 \times 10^{-8} \mathrm{M}\right), \mathrm{ICl}-182,780\left(\mathrm{ICl}, 1 \times 10^{-6} \mathrm{M}\right)$ or its vehicle (C) for $\left.24 \mathrm{hr} . \mathbf{A}\right)$ CCND1 and B) EAG1 gene expression was determined by $\mathrm{qPCR}$. Results shown are the mean \pm S.D. of CCND1 or EAG1/GAPDH mRNA normalized ratio. Data were normalized setting a value of 1 for vehicle-treated cells. ${ }^{*} P \leq 0.05$ vs. C.

Figure $6 \mathrm{~B}$, neither $\mathrm{E}_{2}$ nor ICI-182,780 altered EAG1 gene expression in non-calcitriol treated cells (black bars); however, when compared with cells in the presence of calcitriol, the antiestrogen, in contrast to E2 alone, significantly decreased EAG1 mRNA levels (white bars).

\section{Calcipotriol, a vitamin D analogue, increased $E R a$ expression}

Calcipotriol, a synthetic low calcemic vitamin D analogue, has been considered a potent stimulator of cell differentiation and inhibitor of cell proliferation in cancer cells [35]. Figure 7 shows a comparison between different concentrations of calcipotriol and calcitriol $\left(1 \times 10^{-10}\right.$ to $\left.1 \times 10^{-6} \mathrm{M}\right)$ upon $E R \alpha$ gene expression in SUM-229PE. As depicted, both compounds increased $E R \alpha$ gene expression in a concentrationdependent manner with similar $\mathrm{EC}_{50}$ values $\left(2.74 \times 10^{-8} \mathrm{M}\right.$ and $2.21 \times 10^{-8} \mathrm{M}$, for calcipotriol and calcitriol, respectively).

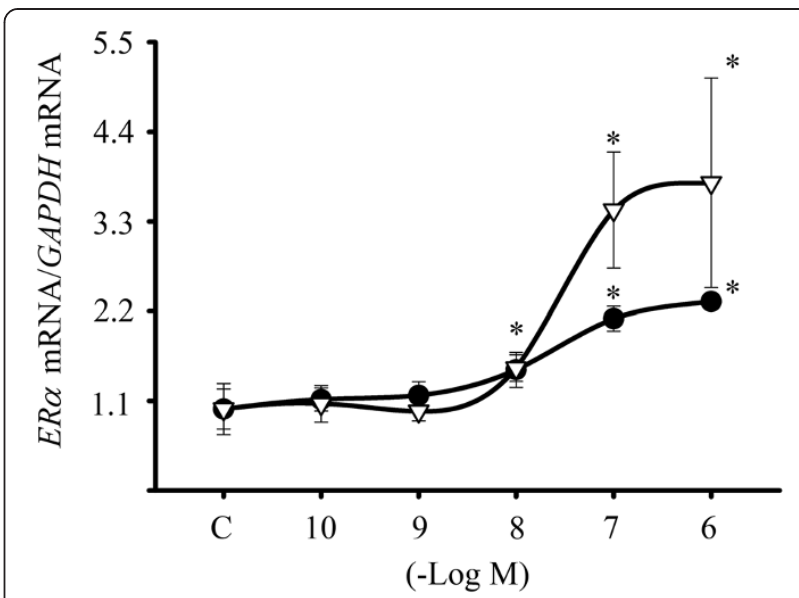

Figure 7 Calcipotriol induced ERa expression in ER-negative breast cancer cells. SUM-229PE cells were cultured in the presence of different calcitriol (circles) and calcipotriol (triangles) concentrations or vehicle alone (C, ethanol) for $24 \mathrm{hr}$. Afterwards, mRNA was extracted and GPCR was performed. Results are shown as the mean \pm S.D. of ERa/GAPDH mRNA normalized ratio. Data were normalized setting a value of 1 for vehicle-treated cells. ${ }^{*} P \leq 0.05$ vs. $C$.

\section{Discussion}

In breast cancer, the presence of the ER $\alpha$ is considered as a good indicator of disease-free survival and prognosis since patients with ER $\alpha$-positive tumors are candidates for hormonal therapy $[3,4,6]$. In contrast, tumors lacking this receptor have the poorest clinical prognosis [36]. In this study we demonstrated the ability of calcitriol to induce the expression of ER $\alpha$ in both primary and established $E R \alpha$-negative breast cancer cell lines. This effect was mediated by a VDR-dependent mechanism. In addition, our results demonstrated a fully active calcitriol-induced ER by its ability to increase $P R L$ gene expression. Interestingly, pretreatment of ER-negative breast tumor-derived cells with calcitriol and the further incubation with this secosteroid in combination with tamoxifen or ICI-182,780 resulted in a significantly lower cell growth proliferation.

It is noteworthy to mention that, to our knowledge, this study is the first to demonstrate the ability of calcitriol to induce the expression of a functional ER $\alpha$ in both primary and established ER $\alpha$-negative breast cancer cells, which we think is of biological importance given its potential for future treatment strategies to improve prognosis in $\mathrm{ER} \alpha$-negative breast cancer patients.

Since it has been observed that MAPK inhibitors increase $\mathrm{ER} \alpha$ protein in ER-negative breast tumor cells [10], we hypothesized that the upregulation of ER $\alpha$ by calcitriol could be the result of decreased MAPK activity. Although, in this study we could not demonstrate any change in this kinase in the presence of calcitriol. An alternative, mechanism by which calcitriol via its receptor induced 
ER $\alpha$ expression might be at the level of promoter-driven transcriptional regulation. Therefore, in order to identify putative vitamin D response elements we performed an in silico analysis with the MatInspector software [37] using a sequence derived from the human chromosome 6, which contains the promoter region of ER $\alpha$ [38]. The results from this analysis showed the presence of several putative vitamin D response elements of the DR3 and DR4 types, supporting the idea of a direct transcriptional regulation of ER promoter by calcitriol.

The observation that tamoxifen and ICI-182,780 inhibited cell growth in calcitriol-treated ER-negative breast tumor-derived cells indicated the induction of a functionally active ER $\alpha$. However, cell growth inhibition by tamoxifen was not observed in the case of calcitriol-treated ER-negative SUM-229PE cells. This finding might be explained as a receptor resistance-like condition resulting probably from the hyperactivation of the MAPK signaling pathway due to overexpression of EGFR or HER2 as has been previously observed in breast cancer cells [10].

It is well known that $E_{2}$ exhibits proliferative effects and therefore stimulates tumor growth in breast cancer $[39,40]$. However, in the present study, the presence of $E_{2}$ did not result in increased proliferation of cells pretreated with calcitriol. It is possible that the lack of mitogenic activity of $E_{2}$ through the newly expressed $E R \alpha$ was due to a priming antiproliferative effect of calcitriol, thus preventing the expected estradiol-mediated effects on cell proliferation. This observation agreed with those of Bayliss et al., [10] who showed that E2 did not increase proliferation in cells where the ER $\alpha$ was reexpressed by MAPK inhibitors, including in those studies in ER-negative breast cancer cells transfected with the ER [41].

In this study, the ability of antiestrogens to inhibit cell growth in an estradiol-depleted condition might require further investigation; however, some effects of these compounds on the mitogenic activity of growth factors, in the absence of estrogens have been already demonstrated in breast cancer [33,42]. In this regard, one of the most common regulators known to be altered and overexpressed in various cancers including breast is CCND1, which functions as mitogenic sensor and allosteric activator of cyclindependent kinase (CDK)4/6 [43]. It is known that the inhibitory actions of antiestrogens on breast cancer are in part exerted through the downregulation of CCND1 [33]. In this study, the results showing that ICI-182,780 significantly decreased CCND1 mRNA only in calcitriol-treated cells, indicated that these compounds may affect cell cycle regulation as has already been shown in ER-positive breast tumors [33]. Furthermore, the demonstration of a significant inhibition of EAG1 gene expression by ICI-182,780 in calcitriol-treated cells, suggested that the antiproliferative effects of these compounds involve a number of regulatory mechanisms which are under the control of ER $\alpha$ activation.
These results suggest that calcitriol in combination with ICI-182,780, through downregulation of EAG1 and CCND1 affect cell proliferation and tumor progression [34,44].

There are several markers associated with tumor aggressiveness. Among these, myoepithelial markers, which are preferentially expressed in ER-negative breast cancer, suggest that the loss of the steroid receptor is related to the degree of cellular dedifferentiation occurring in these tumors [45]. It is known that calcitriol promotes differentiation of several tumor cell types, including human breast and colon cancers $[14,46]$. This process involves the action of calcitriol on a number of events, such as the induction of adhesion proteins (E-cadherin, claudin, occludin) or by interfering with some intracellular signaling pathways, such as the Wnt/b-catenin signaling $[14,46]$. Our results revealed that calcitriol induced $\mathrm{ER} \alpha$ gene and protein expression suggesting that calcitriol affects the phenotype of ER $\alpha$-negative breast cancer cells by reverting cellular mechanisms associated with a more aggressive behavior and poor prognosis.

The development of numerous vitamin D analogues and intermittent calcitriol dosing have allowed substantial dose-escalation and reduced calcemic effects $[47,48]$. Calcipotriol, a synthetic vitamin $\mathrm{D}$ analogue with a significantly lower calcemic effect, is also known as a potent antiproliferative compound and an inducer of cell differentiation [35]. In this study, the demonstration that calcipotriol was also able to upregulate $E R \alpha$ gene expression in an ER-negative breast cancer cell line, suggest that treatment options in breast cancer patients might also include vitamin D analogues with reduced side calcemic effects.

Our results suggest that the use of calcitriol in combination with aromatase inhibitors or ER antagonists might be considered in the future as a new strategy for the treatment of ER $\alpha$-negative breast cancer, including the triple-negative subtypes.

\section{Conclusions}

The results presented herein clearly demonstrated the ability of calcitriol and its synthetic analog calcipotriol to upregulate ER $\alpha$ expression in a subset of ER-negative breast cancer cells. These results may offer a therapeutic alternative, particularly in those patients affected with ER-negative tumors by sensitizing them to hormone therapy, with the aim at improving disease prognosis.

\section{Abbreviations}

CTSD: Cathepsin D; CCND1: Cyclin D1; E2: Estradiol; EAG1: Ether-à-go-go 1; $\mathrm{EC}_{50}$ : Stimulatory concentration; EGFR: Human epidermal growth factor receptor- 1; ER: Estrogen receptor; FBS: Fetal bovine serum;

GAPDH: Glyceraldehyde-3-phosphate dehydrogenase; HER2: Human epidermal growth factor receptor- 2; MAPK: Mitogen-activated protein kinase; PR: Progesterone receptor; PRL: Prolactin; qPCR: Real time polymerase chain reaction; RT: Reverse transcription; S.D: Standard deviation; TFF1: Trefoil factor 1; VDR: Vitamin D receptor 


\section{Competing interests}

The authors declare that they have no competing interests.

\section{Authors' contributions}

RGB and LD were involved in the conception, design and coordination of the study as well as in data analysis, interpretation of results, actively participated in all experimental procedures, and were involved in drafting the manuscript. NSM was in charge of all experimental procedures, participated in data analysis and interpretation, as well as in drafting the manuscript. DOR, JGQ, DB, MJIS and JEL participated in the experimental procedures and revised critically the content of the manuscript. HMF provided breast biopsies, carried out the clinical data collection and retrieved patients signed informed-consent forms. EA, AH and JC contributed in the interpretation of data and critically revised the manuscript for important intellectual content. FL participated in the interpretation of data, made substantive intellectual contribution to the study and drafting the manuscript. All authors read and approved the final manuscript.

\section{Acknowledgments}

This work was supported by grants 129315 and 153862 from the Consejo Nacional de Ciencia y Tecnología (CONACyT), México. The authors state that there are non-financial competing interests. N. Santos-Martínez is a Ph.D, student from the Centro de Investigación y Estudios Avanzados, Instituto Politécnico Nacional (CINVESTAV), México, and recipient of a fellowship from CONACyT. We acknowledge with thanks to Teijin Pharma Limited (Japan), Hoffmann-La Roche Ltd and AstraZeneca for TEl-9647, calcitriol and Gefitinib donations, respectively.

\section{Author details}

'Departments of Reproductive Biology, Instituto Nacional de Ciencias Médicas y Nutrición Salvador Zubirán, Vasco de Quiroga No. 15, Tlalpan 14000 México, México. ${ }^{2}$ Department of Pharmacology, Centro de Investigación y de Estudios Avanzados, I.P.N., Av. Instituto Politécnico Nacional 2508 Gustavo A. Madero, 07360 México, D.F, México. ${ }^{3}$ Department of Surgery, Instituto Nacional de Ciencias Médicas y Nutrición Salvador Zubirán, Vasco de Quiroga No. 15, Tlalpan 14000 México, D.F, México. ${ }^{4}$ Biochemistry Unit. Instituto Nacional de Ciencias Médicas y Nutrición Salvador Zubirán, Vasco de Quiroga No. 15, Tlalpan 14000 México, D.F, México.

Received: 24 September 2013 Accepted: 25 March 2014 Published: 29 March 2014

\section{References}

1. Simpson PT, Reis-Filho JS, Gale T, Lakhani SR: Molecular evolution of breast cancer. J Pathol 2005, 205(2):248-254.

2. Sorlie T, Perou CM, Tibshirani R, Aas T, Geisler S, Johnsen H, Hastie T, Eisen MB, van de Rijn M, Jeffrey SS, Thorsen T, Quist H, Matese JC, Brown PO, Botstein D, Eystein Lonning P, Borresen-Dale AL: Gene expression patterns of breast carcinomas distinguish tumor subclasses with clinical implications. Proc Nat Acad Sci U S A 2001, 98(19):10869-10874.

3. Clark GM, McGuire WL: Steroid receptors and other prognostic factors in primary breast cancer. Semin Oncol 1988, 15(2 Suppl 1):20-25.

4. McGuire WL, Osborne CK, Clark GM, Knight WA 3rd: Steroid hormone receptors and carcinoma of the breast. Am J Physiol 1982, 243(2):E99-E102.

5. Nadji M, Gomez-Fernandez C, Ganjei-Azar P, Morales AR: Immunohistochemistry of estrogen and progesterone receptors reconsidered: experience with 5,993 breast cancers. Am J Clin Pathol 2005, 123(1):21-27.

6. Powles TJ, Ashley S, Tidy A, Smith IE, Dowsett M: Twenty-year follow-up of the Royal Marsden randomized, double-blinded tamoxifen breast cancer prevention trial. J Natl Cancer Inst 2007, 99(4):283-290.

7. Clarke MJ: WITHDRAWN: Tamoxifen for early breast cancer. Cochrane Database Syst Rev 2008, 4, CD000486.

8. Johnston SR: Acquired tamoxifen resistance in human breast cancer-potential mechanisms and clinical implications. Anticancer Drugs 1997, 8(10):911-930.

9. Zhao JJ, Lin J, Yang H, Kong W, He L, Ma X, Coppola D, Cheng JQ: MicroRNA-221/222 negatively regulates estrogen receptor alpha and is associated with tamoxifen resistance in breast cancer. J Biol Chem 2008, 283(45):31079-31086.
10. Bayliss J, Hilger A, Vishnu P, Diehl K, El-Ashry D: Reversal of the estrogen receptor negative phenotype in breast cancer and restoration of antiestrogen response. Clin Cancer Res 2007, 13(23):7029-7036.

11. Oh AS, Lorant LA, Holloway JN, Miller DL, Kern FG, El-Ashry D: Hyperactivation of MAPK induces loss of ERalpha expression in breast cancer cells. Mol Endocrinol 2001, 15(8):1344-1359.

12. Fife RS, Sledge GW Jr, Proctor C: Effects of vitamin D3 on proliferation of cancer cells in vitro. Cancer Lett 1997, 120(1):65-69.

13. Simboli-Campbell M, Narvaez CJ, Tenniswood M, Welsh J: 1,25-Dihydroxyvitamin D3 induces morphological and biochemical markers of apoptosis in MCF-7 breast cancer cells. J Steroid Biochem Mol Biol 1996, 58(4):367-376.

14. Pendas-Franco N, Gonzalez-Sancho JM, Suarez Y, Aguilera O, Steinmeyer A, Gamallo C, Berciano MT, Lafarga M, Munoz A: Vitamin D regulates the phenotype of human breast cancer cells. Differentiation 2007, 75(3):193-207.

15. Janowsky EC, Lester GE, Weinberg CR, Millikan RC, Schildkraut JM, Garrett PA, Hulka BS: Association between low levels of 1,25-dihydroxyvitamin D and breast cancer risk. Public Health Nutr 1999, 2(3):283-291.

16. Mawer EB, Walls J, Howell A, Davies M, Ratcliffe WA, Bundred NJ: Serum 1,25-dihydroxyvitamin $D$ may be related inversely to disease activity in breast cancer patients with bone metastases. J Clin Endocrinol Metab 1997, 82(1):118-122.

17. Yao S, Ambrosone CB: Associations between vitamin D deficiency and risk of aggressive breast cancer in African-American women. J Steroid Biochem Mol Biol 2012, 136:337-341.

18. Berger U, McClelland RA, Wilson P, Greene GL, Haussler MR, Pike JW, Colston K, Easton D, Coombes RC: Immunocytochemical determination of estrogen receptor, progesterone receptor, and 1,25-dihydroxyvitamin D3 receptor in breast cancer and relationship to prognosis. Cancer Res 1991, 51(1):239-244.

19. Garcia-Becerra R, Diaz L, Camacho J, Barrera D, Ordaz-Rosado D, Morales A, Ortiz CS, Avila E, Bargallo E, Arrecillas M, Halhali A, Larrea F: Calcitriol inhibits Ether-a go-go potassium channel expression and cell proliferation in human breast cancer cells. Exp Cell Res 2010.

20. Swami S, Krishnan AV, Feldman D: 1alpha,25-Dihydroxyvitamin D3 down-regulates estrogen receptor abundance and suppresses estrogen actions in MCF-7 human breast cancer cells. Clin Cancer Res 2000, 6(8):3371-3379.

21. Garcia-Quiroz J, Garcia-Becerra R, Barrera D, Santos N, Avila E, Ordaz-Rosado D, Rivas-Suarez M, Halhali A, Rodriguez P, Gamboa-Dominguez A, Medina-Franco H, Camacho J, Larrea F, Diaz L: Astemizole synergizes calcitriol antiproliferative activity by inhibiting CYP24A1 and upregulating VDR: a novel approach for breast cancer therapy. PLoS One 2012, 7(9):e45063.

22. Simboli-Campbell M, Narvaez CJ, van Weelden K, Tenniswood M, Welsh J: Comparative effects of 1,25(OH)2D3 and EB1089 on cell cycle kinetics and apoptosis in MCF-7 breast cancer cells. Breast Cancer Res Treat 1997, 42(1):31-41.

23. Stoica A, Saceda M, Fakhro A, Solomon HB, Fenster BD, Martin MB: Regulation of estrogen receptor-alpha gene expression by 1,25-dihydroxyvitamin $D$ in MCF-7 cells. J Cell Biochem 1999, 75(4):640-651.

24. Davoodi F, Brenner RV, Evans SR, Schumaker LM, Shabahang M, Nauta RJ, Buras RR: Modulation of vitamin D receptor and estrogen receptor by 1,25(OH)2-vitamin D3 in T-47D human breast cancer cells. J Steroid Biochem Mol Biol 1995, 54(3-4):147-153.

25. Li Z, Bustos V, Miner J, Paulo E, Meng ZH, Zlotnikov G, Ljung BM, Dairkee SH: Propagation of genetically altered tumor cells derived from fine-needle aspirates of primary breast carcinoma. Cancer Res 1998, 58(23):5271-5274.

26. Tesch M, Shawwa A, Henderson R: Immunohistochemical determination of estrogen and progesterone receptor status in breast cancer. Am J Clin Pathol 1993, 99(1):8-12.

27. Maurer $U$, Jehan F, Englert C, Hubinger G, Weidmann E, DeLuca HF, Bergmann L: The Wilms' tumor gene product (WT1) modulates the response to 1,25-dihydroxyvitamin D3 by induction of the vitamin D receptor. Biol Chem 2001, 276(6):3727-3732.

28. Lappano R, Recchia AG, De Francesco EM, Angelone T, Cerra MC, Picard D, Maggiolini M: The cholesterol metabolite 25-hydroxycholesterol activates estrogen receptor alpha-mediated signaling in cancer cells and in cardiomyocytes. PloS one 2011, 6(1):e16631.

29. Almeras L, Eyles D, Benech P, Laffite D, Villard C, Patatian A, Boucraut J, Mackay-Sim A, McGrath J, Feron F: Developmental vitamin D deficiency alters brain protein expression in the adult rat: implications for neuropsychiatric disorders. Proteomics 2007, 7(5):769-780. 
30. Hussain-Hakimjee EA, Mehta RG: Regulation of steroid receptor expression by 1alpha-hydroxyvitamin D5 in hormone-responsive breast cancer cells. Anticancer Res 2009, 29(9):3555-3561.

31. Duan R, Ginsburg E, Vonderhaar BK: Estrogen stimulates transcription from the human prolactin distal promoter through AP1 and estrogen responsive elements in T47D human breast cancer cells. Mol Cell Endocrinol 2008, 281(1-2):9-18.

32. Musgrove EA, Hamilton JA, Lee CS, Sweeney KJ, Watts CK, Sutherland RL: Growth factor, steroid, and steroid antagonist regulation of cyclin gene expression associated with changes in T-47D human breast cancer cell cycle progression. Mol Cell Biol 1993, 13(6):3577-3587.

33. Watts CK, Sweeney KJ, Warlters A, Musgrove EA, Sutherland RL: Antiestrogen regulation of cell cycle progression and cyclin D1 gene expression in MCF-7 human breast cancer cells. Breast Cancer Res Treat 1994, 31(1):95-105.

34. Pardo LA, Suhmer W: Eag1 as a cancer target. Expert Opin Ther Targets 2008, 12(7):837-843.

35. Binderup L, Bramm E: Effects of a novel vitamin D analogue MC903 on cell proliferation and differentiation in vitro and on calcium metabolism in vivo. Biochem Pharmacol 1988, 37(5):889-895.

36. Osborne CK, Yochmowitz MG, Knight WA 3rd, McGuire WL: The value of estrogen and progesterone receptors in the treatment of breast cancer. Cancer 1980, 46(12 Suppl):2884-2888.

37. Cartharius K, Frech K, Grote K, Klocke B, Haltmeier M, Klingenhoff A, Frisch M, Bayerlein $M$, Werner T: Matlnspector and beyond: promoter analysis based on transcription factor binding sites. Bioinformatics 2005, 21(13):2933-2942.

38. Kos M, Reid G, Denger S, Gannon F: Minireview: genomic organization of the human ERalpha gene promoter region. Mol Endocrinol 2001, 15(12):2057-2063.

39. Doisneau-Sixou SF, Sergio CM, Carroll JS, Hui R, Musgrove EA, Sutherland RL: Estrogen and antiestrogen regulation of cell cycle progression in breast cancer cells. Endocr Relat Canc 2003, 10(2):179-186.

40. Dickson RB, Lippman ME: Growth factors in breast cancer. Endocrine reviews 1995, 16(5):559-589.

41. Jiang SY, Jordan VC: Growth regulation of estrogen receptor-negative breast cancer cells transfected with complementary DNAs for estrogen receptor. J Natl Cancer Inst 1992, 84(8):580-591.

42. Vignon F, Bouton MM, Rochefort $\mathrm{H}$ : Antiestrogens inhibit the mitogenic effect of growth factors on breast cancer cells in the total absence of estrogens. Biochem Biophys Res Commun 1987, 146(3):1502-1508.

43. Barnes DM, Gillett CE: Cyclin D1 in breast cancer. Breast Cancer Res Treat 1998, 52(1-3):1-15.

44. Ouadid-Ahidouch $\mathrm{H}$, Ahidouch $\mathrm{A}$ : $\mathrm{K}+$ channel expression in human breast cancer cells: involvement in cell cycle regulation and carcinogenesis. J Membr Biol 2008, 221(1):1-6.

45. Gordon LA, Mulligan KT, Maxwell-Jones H, Adams M, Walker RA, Jones JL: Breast cell invasive potential relates to the myoepithelial phenotype. Int J Cancer 2003, 106(1):8-16.

46. Palmer HG, Gonzalez-Sancho JM, Espada J, Berciano MT, Puig I, Baulida J, Quintanilla M, Cano A, de Herreros AG, Lafarga M, Munoz A: Vitamin D (3) promotes the differentiation of colon carcinoma cells by the induction of E-cadherin and the inhibition of beta-catenin signaling. J Cell Biol 2001, 154(2):369-387.

47. Beer TM, Munar M, Henner WD: A Phase I trial of pulse calcitriol in patients with refractory malignancies: pulse dosing permits substantial dose escalation. Cancer 2001, 91(12):2431-2439.

48. Masuda S, Jones G: Promise of vitamin D analogues in the treatment of hyperproliferative conditions. Mol Cancer Ther 2006, 5(4):797-808.

\section{Submit your next manuscript to BioMed Central and take full advantage of:}

- Convenient online submission

- Thorough peer review

- No space constraints or color figure charges

- Immediate publication on acceptance

- Inclusion in PubMed, CAS, Scopus and Google Scholar

- Research which is freely available for redistribution

Submit your manuscript at www.biomedcentral.com/submit 